en Indisch Genootschap en besluit daarom den Secretaris te machtigen tot aankoop van een boekenkast.

De Vergadering wordt door den Voorzitter gesloten.

\title{
137ste BESTUURSVERGADERING.
}

\section{November 1871.}

Tegenwoordig de heeren Gevers Deynoot (Voorzitter), Robidé van der Aa, Bachiene, van Limburg Brouwer, Blommendal, Dumontier, Meinsma en Niemann.

De notulen van het verhandelde in de vorige vergadering worden gelezen en goedgekeurd.

I. Voor de bibliotheek zijn ingezonden de volgende werken : Van het Departement van Koloniën :

Het Ombiliën-kolenveld in de Padangsche bovenlanden en het transportstelsel op Sumatra's Westkust.

Van het Bataviaasch Genootschap van kunsten en wetenschappen:

Tijdschr. voor Indische taal-, land- en volkenkunde, deel XVIII, afl. 3 .

Notulen van de alg. en bestuursverg. deel IX, no. 1.

Van de Nederlandsche maatschappij tot bevordering van nijverheid:

Handelingen der 94, ste alg. vergadering;

Tijdschrift, $3 \mathrm{e}$ reeks, deel XII, 7e en 8e stuk.

Van de Kon. Pruissische akademie van wetenschappen te Berlijn:

Monatsberichte Juli en Aug. 1871.

Van de Société de géographie te Parijs:

Bulletin afl. Aug.-Oct. 1871.

Van den heer Angelo de Gubernatis :

La Rivista Europea. Anno 11, vol. IV, fasc. 1-2.

Van den heer L. Am. Sédillot.

Des connaissances scientifiques des Orientaux à propos des étymologies arabes.

Observations sur les termes empruntés à la langue arabe.

Des emprunts faits par les français à la langue arabe.

Van den heer J. Hageman JCzn.:

Tengger, gebergte en bevolking, 
II. De Voorzitter deelt mede dat zijn ingekomen de volgende missives:

10. van de heeren dr. T. C. L. Wijnmalen en V. M. C. E. le Rütte, te 's Gravenhage, houdende kennisgeving dat zij het aangeboden lidmaatschap aannemen.

20. Van de heeren Winsser, de Lange en Co. te Batavia, dd. 30 Augustus jl., waarbij aan het Instituut kennis wordt gegeven van in kas genomen gelden, die betaalbaar zijn bij den heer F. L. der Kinderen te 's Gravenhage.

De penningmeester zegt dat, ofschoon door de welwillende tusschenkomst van de heeren Winsser, de Lange en Co. te Batavia eenig bedrag van de achterstallige contributie aan het Instituut voldaan is, nog steeds eene zeer belangrijke som door de verschillende leden aan het Instituut verschuldigd blijft, hetgeen voornamelijk hieraan is te wijten dat de firma Winsser. de Lange en Co. wel de haar toegezonden gelden ter voldoening van verschuldigde contributie in ontvangst neemt, maar geenszins die gelden bij de leden doet innen. De goede uitslag van den genomen maatregel, een gevolg van het welwillend aanbod der genoemde firma, is dus voornamelijk afhankelijk van den goeden wil en de belangstellende medewerking der leden. En aangezien het niet te verwachten is dat de leden in het vervolg meer belangstelling zullen toonen dan tot dusver, zou het bestuur in de noodzakelijkheid kunnen gebracht worden naar een ander middel om te zien ten einde de ontvangst der verschuldigde contributie te verzekeren. De penningmeester geeft daarom in overweging commissarissen te Batavia over dit onderwerp te schrijgen en hun gevoelen te verzoeken over de vraag: of de inning der contributie ook zou kunnen worden opgedragen, onder toezicht en verantwoordelijkheid van commissarissen, aan iemand te Batavia, die commissarissen voor dit werk geschikt oordeelen en waarvoor de noodig geoordeelde uitgaven aan het Instituut in rekening zouden kunnen worden gebracht.

De vergadering besluit overeenkomstig het denkbeeld van den penningmeester, zoodat aan den secretaris wordt opgedragen commissarissen te Batavia te verzoeken hun gevoelen mede te deelen omtrent het bedoelde onderwerp.

III. Uitgave van een handschrift over Chilolo. De Secretaris zegt dat dit handschrift, dat zich in het arehief van het Instituut bevindt, ter opnemüng in de Bijdragen bestemd is. 
Het is wenschelijk geoordeeld bij dit opstel eene kaart te voegen van de landstreek, waarop het opstel betrekking heeft. De vergadering verleent hare toestemming tot het vervaardigen dier kaart, waartoe het bestuurslid de heer Blommendal zijne tusschenkomst heeft toegezegd.

\section{Uitgave der babah tunah Djawi of Javaansche kroniek.} De commissie, bestaande uit de heeren Niemann en Kern, brengt omtrent dit werk het volgende verslag uit:

" Het is u bekend dat ous geacht medelid, de heer Meinsma, oulangs het voorstel heeft gedaan dat het Instituut eene door hem bewerkte babad tanah Djawi of zooggenaamde javaansche kronijk zou uitgeven. De ondergeteekenden, door uwe vergadering uitgenoodigd een rapport omtrent deze zaak uit te brengen, hebben hierbij de eer zich van die opdracht te kwijten.

"Het door den heer Meinsma voor de uitgave bewerkte geschrift is een dier weinige javaansche werken, die in proza zijn opgesteld en behelst de over het geheel van elders reeds bekende oude legenden der Javanen en voorts de javaansche voorstellingen omtrent het ontstaan van het groote rijk van Mataram, terwijl het vooral ook over de betrekkingen der Javanen tot de Nederlanders handelt. Het loopt ongeveer tot het jaar 1722 van onze jaartelling, het einde namelijk van den zoogenaamden tweeden Java-oorlog, hoewel het verhaal daarmede niet geheel en al sluit. De inhoud komt dus grootendeels overeen met hetgeen door Raffles, Hageman en Wilkens (in het Tijdschr. v. Nederl. Indie) over bovenvermelde onderwerpen is medegedeeld. De taal is zuiver Soerakartasch-Javaansch, bijna zonder poëtische woorden en voor een vreemdeling, die tot zekere hoogte met de taal bekend is, niet moeilijk te verstaan. Als schrijver wordt de Javaan Kĕrtå Prådjå genoemd.

"Wat den omvang van dit geschrift betreft, daaromtrent valt alleen dit te vermelden, dat het, indien het gedrukt werd met dezelfde kleine javaansche drukletter als die der tweede uitgave van Winter's Javaansche Zamenspraken, le stuk, ongeveer 350 bladzijden, dus 22 vel druks, zou beslaan, behalve de aanteekeningen. Omtrent de uitgebreidheid dezer laatste kan de heer Meinsma op dit oogenblik moeilijk eene bepaalde opgave doen; het is echter zijn voornemen die zoo beknopt te maken als met eene goede uitgave bestaanbaar zal zijn; naar oppervlak. 
kige raming zullen zij hoogstens $100-130$ bladz, bedragen. Uwe commissie herinnert $\mathrm{u}$ hierbij dat zij, zooals haar vroeger was opgedragen, reeds met uitgevers over de zaak der uitgave gesproken heeft en dat de heer Nijhoff te 's Hage verklaard heeft die zonder eenig subsidie van het Instituut te willen ondernemen, indien het goevernement bereid mocht zijn die te ondersteunen door eene bestelling van 200 exemplaren.

"Ofschoon wij ons reeds vroeger ten gunste der uitgave van deze babad verklaard hebben, achten wij het toch niet ongepast $\mathrm{u}$ die bij deze gelegenheid noginaals aan te bevelen. Vooreerst toch hebben wij hier te doen met een werk in proza, terwijl de javaansche letterkunde, gelijk boven reeds ter loops is opgemerkt, slechts zeẹr weinige geschriften in proza telt, maar hoofdzakelijk urt geschriften in dichtmaat bestaat. De gebreken en bezwaren aan dien vorm verbonden, die wij hier niet nader behoeven uiteen te zetten, maken de uitgave van goede prozageschriften alleszins wenschelijk, zoodat de druk van deze babah niet alleen van belang is voor de nadere kennis der taal, maar ook in de dringende behoefte zou voorzien van een goed leesboek ten gebruike zoowel van Europeanen, die zich op het Javaansch toeleggen als van de leerlingen der inlandsche scholen op Java.

"Terwijl voorts de mythische overleveringen der Maleiers, in de zoogenaamde Sědjarah Mălajoe vervat en verscheidene latere maleische kronijken reeds lang geleden in het licht zijn verschenen, terwijl het voornaamste uit de makassaarsche en boeginesche kronijken reeds publiek is gemaakt, bezitten wij nog altijd geene tekstuitgave van die der Javanen, zoodat ook uit dit literarisch oogpunt de uitgave wenschelijk is te achten. Te neer is dit het geval, daar wij hier niet enkel en alleen fabelachtige legenden vinden, maar de genoemde babah ook genoeg historische bestanddeelen bevat, die voor de beoefening der geschiedenis van Java wel is waar van geen overwegend belang zijn, maar toch op verre na niet van gewicht ontbloot ter vergelijking met andere berichten, zooals o. a. kan blijken uit het opstel van den heer Meinsma getiteld: "Het fort te Kartasoera in 1741" (in de Bijdragen van het Instituut, Nieuwe volgreeks deel VI). Bovendien kan de javaansche tekst ons inlichten omtrent de juiste schrijfwijze van vele eigennamen, die in de geschiedenis van Java voorkomẹn en waaromtrent wịj thans meermalen in het onzekere verkeeren.

"Voegen wij aan het gezegde nog toe dat de bewerking van 
dit geschrift voor de uitgave aan een grondig kenner der javaansche taal als de heer Meinsma toevertrouwd zou zijn en dat hem daartoe meer dan een goed handschrift ter beschikking staat, dan meenen wij ons te mogen verheugen over de gelegenheid hier aangeboden ter bevordering van het doel van het Instituut."

Dit rapport zal den minister van kolonien in afschrift worden toegezonden. met eene geleidende missive van het bestuur, waarin het verzoek wordt gedaan om door eene bestelling van tweehonderd exemplaren door het departement van kolonien het Instituut in de gelegenheid te stellen de uitgave van het werk te ondernemen, een verzoek dat het bestuur meent te mogen doen, omdat, zooals in het verslag der commissie staat opgeteekend, de druk der babad niet alleen van belang wordt geacht voor de nadere kennis der javaansche taal, voor de geschiedenis van Java en voor de juiste schrijfwijze van vele eigennamen, die in de geschiedenis voorkomen, maar ook omdat het werk zou voorzien in de dringende behoefte van een goed leesboek ten gebruike zoowel van Europeanen, die zich op het Javaansch toeeeggen als van de leerlingen der inlandsche scholen op Java.

V. Balineesch handschrift. De secretaris zegt dat de heer Hingman, ambtenaar bij het Rijksarchief, aan het lnstituut heeft aangeboden een Balineesch handschrift op lontarbladen, voor welk geschenk den heer Hingman den dank van het bestuur zal worden betuigd.

\section{Mededeeling omtrent het plan tot het houden in 1872} van een geografisch congres te Amsterdam. De heer Bachiene, ofschoon verhinderd het jongste congres te Antwerpen bij te wonen, maar die toch een opstel aan het Congresbestuur heeft ingezonden, heeft met eenige andere heeren, die uit Nederland de vergaderingen van het Congres bijwoonden, de uitnoodiging ontvangen maatregelen te beramen ten einde in den loop van 1872 een bijeenkomst van het Congres te Amsterdam te doen plaats vinden. Mocht aan dit denkbeeld uitvoering kunnen gegeven worden, dan zou het op prijs worden gesteld wanneer daaraan het Iustituut zijne medewerking verleende. De vergadering heeft met belangstelling deze mededeeling gehoord en 
zal gaarne later vernemen of aan het plan uitvoering wordt gegeven.

\section{Plan van vereeniging van het Koninklijk Instituut} met het Indisch Genootschap. De Voorzitter zegt dat de door den heer Cornets de Groot ingezonden stukken bij de leden van het bestuur in rondlezing zijn geweest en dat het wenschelijk is alsnu eene beslissing omtrent het plan van vereeniging te nemen.

De heer Bachiene ondersteunt het plan. Men zou toch het Genootschap, dat na de vereeniging zou in het leven treden, uit twee afdeelingen kunnen doen bestaan, de eene werkzaam in den geest van het Instituut, de andere in dien van het Genootschap. De vereeniging is vooral aan te bevelen omdat, zoo daartoe thans al geene dringende reden mocht bestaan, toch op den duur om finantieele redenen eene zelfstandige werking der twee Genootschappen niet behouden zal kunnen worden.

Van de andere zijde wordt herinnerd aan de bezwaren herhaaldelijk tegen het plan van vereeniging geopperd. Uit een finantieel oogpunt vooral verdient het plan geen aanbeveling. $\mathrm{Nu}$ toch zijn vele personen lid van beide genootschappen, die dien tengevolge eene jaarlijksche contributie van $f 20$ betalen. Die contributie zou, in geval van samensmelting, niet op dat bedrag kunnen, zelfs op een aanmerkelijk lager cijfer moeten gesteld worden, waarvan het gevolg zou zijn dat de werkzaamheden van het Instituut, die o. a. bestaan in het uitgeven van dikwijls zeer kostbare werken, aanmerkelijk ingekrompen zouden worden. Ook is het te verwachten dat vele personen, èn om politieke èn om andere redenen in dẹ verandering aanleiding zouden vinden om voor hun lidmaatschap te bedanken, zoodat het allicht mogelijk zou zijn dat het ledencijfer aanmerkelijk zou dalen. Bovendien wordt opgemerkt dat thans geene bepaalde reden bestaat voor de vereeniging. De Voorzitter geeft in overweging thans de vraag te beslissen: is op dit oogenblik de vereeniging van Instituut en Indisch Genootschap wenschelijk? Die vraag wordt met 6 tegen 2 stemmen in ontkennenden zin beslist.

De Vergadering wordt door den Voorzitter gesloten. 